\title{
Digital Marketing during the COVID-19 Pandemic: A Case Study of its Adoption by Furniture Manufacturers in Malaysia
}

\author{
Jegatheswaran Ratnasingam, ${ }^{\mathrm{a}, *}$ Natkuncaran Jegathesan, ${ }^{\mathrm{b}}$ Hazirah Ab Latib, ${ }^{\mathrm{a}}$ Florin Ioras, ${ }^{\mathrm{c}}$ \\ Manohar Mariapan, ${ }^{\mathrm{a}}$ and Lim Choon Liat ${ }^{\mathrm{a}}$
}

\begin{abstract}
Contemporary furniture marketing platforms that are based on furniture exhibitions, retail malls, and galleries were severely disrupted by the global COVID-19 pandemic. Therefore, this study was conducted to evaluate the extent to which digital marketing tools were adopted by furniture manufacturers in Malaysia. The effectiveness of digital marketing tools was assessed as an alternative furniture marketing medium by means of a questionnaire distributed to various furniture suppliers. The results of the questionnaire indicated that the onset on the COVID-19 pandemic accelerated the adoption of digital marketing among furniture manufacturers of all sizes. Larger manufacturers had the financial means to make greater investments into digital marketing to utilize it compared to the small and medium-sized enterprises (SMEs). Digital marketing by website, email, and social media were the most common mediums used by furniture manufacturers. As for social media applications, Facebook, Twitter, and Instagram were the common platforms used by furniture manufacturers. Although some furniture manufacturers were familiar with digital marketing, many were not using it effectively due to a lack of skilled workers with the ability to manage such digital marketing tools. Limited financial capital, especially among the SMEs, also made it difficult to enable the adoption of digital marketing.
\end{abstract}

Keywords: Digital Marketing; Furniture; SMEs; Fashion; Sales; Value; COVID-19; Malaysia

Contact information: a: Universiti Putra Malaysia, Faculty of Forestry \& Environment, 43400 UPM, Serdang, Selangor, Malaysia; b: Faculty of Business, University of Wollongong, NSW 2522, Australia;

c: Centre for Sustainability, Buckinghamshire New University, Queen Alexandra Road, High Wycombe, HP11 2JZ Bucks, England; *Corresponding author: jswaran1965@gmail.com

\section{INTRODUCTION}

The Malaysian furniture industry is an important socioeconomic sector within the resource-based economy in Malaysia. In 2019, Malaysia's furniture exports totaled RM 11.38 billion, with wooden furniture making up 83\% of this (MTIB 2020). Malaysia's domestic market for furniture is valued at RM 8.9 billion, and an additional RM 7.5 billion can be attributed to related activities, so the furniture industry's importance cannot be understated. Further, the furniture industry provides employment to 105,000 people, which clearly underlines its importance to Malaysia's economy (MTIB 2020).

Furniture can be made of many different types of materials, such as wood, bamboo, rattan, metal, plastic, leather, and wood-panels. However, there is an unsustainable supply of these materials and they are expensive compared to wooden furniture. These factors have made wooden furniture manufacturing the largest component of Malaysia's production and export volume (Ratnasingam 2017). According to MTIB (2019), wooden 
furniture has consistently made up almost $85 \%$ of the total volume of furniture produced and exported from Malaysia since the late 1980's. The production capacity of the Malaysian furniture industry was valued at RM 23 billion in 2018, which makes Malaysia one of the largest furniture producing nations in the Asian region. After China and Vietnam, Malaysia is the $3^{\text {rd }}$ largest furniture exporting nation in Asia and the $12^{\text {th }}$ largest in the world (MTIB 2020).

The Malaysian furniture industry is predominately composed of small and medium enterprises (SMEs), which make up almost $85 \%$ of all the registered furniture manufacturing enterprises in the country. Small and medium enterprises are firms with annual sales that do not exceed RM 50 million, or less than 200 full-time employees on staff (SME Corp. 2017). The SMEs are the backbone of Malaysia's furniture manufacturing industry, so any impact on the performance of Malaysia's SMEs, due to external or internal factors, may significantly affect the performance of the country's manufacturing sector (MIDA 2019).

\section{Digital Marketing}

The potential of the internet as a medium for marketing is well documented in many publications (Hoffman et al. 1995; Jarvenpaa and Todd 1996). In the wood products and furniture industry, the application of the internet for marketing, better known as ecommerce or digital marketing, has been relatively well established (Vlosky and Westbrook 2002). However, there is no proven method of success that can help management evaluate how beneficial digital marketing may be before they commit substantial capital investment on internet marketing and risk the possibility of interfering with their current channels. This issue is even more important in the wood products and furniture industries, where products are often sold after physical examination in dedicated showrooms, malls, retail outlets, global fairs, and exhibitions (Ratnasingam 2017).

Decisions on marketing channels are among the most critical decisions facing the management of furniture companies, as furniture is often sold based on the perceived value rather than actual value (Ratnasingam 2017). The effectiveness of digital marketing through any digital platforms for furniture remains unknown, and often a combination of both digital marketing and conventional marketing channels have been used consistently by furniture companies throughout the world. In fact, the accelerated application of digital marketing as the sole channel for marketing-activities among furniture manufacturers became very apparent since the onset of the global coronavirus disease 2019 (COVID-19) pandemic in early 2020 (Ratnasingam et al. 2020).

Marketing channels can be divided broadly into direct and indirect marketing approaches (Kotler 1997). Most companies do not sell their products or services directly to the final users for three important reasons: The lack of financial resources to see the negotiations through, the decreased cost-effectiveness when selling low-price consumer goods directly, and the priority to focus on the core business (Kotler 1997). It must be recognized that digital marketing shares some of the characteristics of both direct and indirect marketing forms. In the rapidly digitizing world, the role of digital marketing cannot be downplayed, especially when physical marketing activities are no longer possible.

Establishing a new normal for marketing in the post-pandemic world requires a new approach. Surviving in the age of the empowered customer, with less physical meeting and social distancing renders the traditional mass-marketing tactics almost useless. In this context, understanding the role of technology in shaping the marketplace and, more 
importantly, engaging the social media as part of the marketing toolbox becomes a strategic imperative (Constantinides 2014). Social media platforms have made customers more sophisticated and has paved the way for the development of new tactics in searching, evaluating, choosing, and buying goods and services (Albors et al. 2008). Previous research has shown that customer behavioral trends are increasingly rooted in social media usage, especially among the generation-Y consumers. Digitalization has also increased the demand for customized products and has opened opportunities for customers to get actively involved in the process of product development (Kim et al. 2008; Drury 2008). As customers want to have more influence in various stages of the business process, such developments have influenced the way marketers operate and affect marketing practices on the strategic and tactical levels, which has presented marketers with difficult choices and challenges (Winer 2009). Some of the largest furniture retailers in the United States and the European Union are allowing greater product customization, where marketers fulfil the ideas and wishes of consumers by incorporating these requirements into the finished furniture products. This practice is known as co-creation, and it allows the customers to share their ideas in product development and testing to ensure that the demands of customers are met (Papadopoulos et al. 2015).

The COVID-19 pandemic has increased the competitive pressure among furniture retailers significantly, while challenging all aspects of the business environment. Furniture manufacturers and retailers are determined to regain some control over the customercontrolled social media space, which has prompted many businesses to invest in social media presence, especially during the global pandemic. In an earlier report by Barwise and Styler (2003), it was suggested that with rapid globalization, manufacturers and retailers must develop plans to launch marketing activities in the digital space. This would require the use of various platforms to attract the attention of tech-savvy younger customers in the future. While the market development and market penetration of a firm's products are very important growth strategies for furniture manufacturers and retailers in the globalized world with extended supply-chains, the impact of digital marketing on international market growth has not been well researched (Lim et al. 1993; Mathews and Healy 2007).

\section{Application of Digital Marketing Among SMEs}

Previous studies have shown that digital marketing has a positive impact on international market growth, but there is little evidence to show a significant relationship (Clarke 2008). The importance of digital marketing, especially for export-oriented industries, has been highlighted in several studies (Hamill and Gregory 1997; Eid and ElGohary 2011; Ratnasingam et al. 2020). However, in the case of traditional industries, such as the furniture industry, it is challenging to utilize digital marketing to achieve clear product differentiation and provide adequate services that ensure value and customer fidelity. Furniture manufacturing is the most important sub-sector within the overall Malaysian wood products industry. The dominance of SMEs in the furniture manufacturing sector imposes further challenges due to the variable capacities to adopt digitalization and to invest into the supporting technologies.

The SMEs in the furniture industry strive for quick operations and the fast delivery of their goods. Hence, effective marketing and prompt delivery of the products govern the viability of the SMEs in the furniture sector, so it is no surprise that marketing is among the top three important ingredients that make a successful furniture business (Ratnasingam and Lee 2015). In an earlier study by Ratnasingam et al. (2020), it was shown that most SMEs in Malaysia were affected greatly by the financial and market disruptions during the 
COVID-19 pandemic. Most SMEs have not made substantial investments in information technology (IT) infrastructures, and the onset of the COVID-19 pandemic exposed their unpreparedness to make the transition to digital tools (Ratnasingam et al. 2020). The government of Malaysia recognized the challenges faced by the overall manufacturing sector in the country and implemented an extensive assistance program in 2020 to help the SMEs cope with the challenges, but the effectiveness of this program has not been studied. Although digital marketing has been encouraged and various incentives have been provided through the Malaysian Digital Economy Corporation (MDEC) to encourage SMEs to minimize their market disruptions, the effectiveness and the extent of digital marketing adoption among SMEs in the furniture industry has not been studied.

Therefore, a study was conducted to examine the extent of digital marketing and the specific marketing platforms adopted among Malaysian SMEs in the furniture industry during the COVID-19 pandemic. This study aimed to provide recommendations on possible support measures from the government to enable the SMEs in Malaysia to resume normal operations when future circumstances allow. The results of this study have farreaching implications, as the sustainability of the Malaysian furniture industry is dependent on the strength of its SMEs. This study will also evaluate the extent to which digitalization has been embraced within Malaysia.

\section{METHODOLOGY}

This study was part of a larger study commissioned by the Malaysian Furniture Council (MFC) to collect and compile information on the challenges faced by its members during the Covid-19 pandemic. It was based on the hypothesis that the application of digital tools had increased during the pandemic, especially for marketing activities. The methodology of this study was based on the use of a specially constructed questionnaire that was pre-tested and edited to ensure ease of implementation. The questionnaire was addressed to all 2,417 members of the MFC, which represent furniture manufacturers of small, medium, and large-sized enterprises. The questionnaire was conducted using Google Forms. The link to the survey was initially emailed to all 2,417 potential respondents in the MFC, but only 743 companies agreed to participate in the study. The questionnaire had four parts. Part 1 collected information on the background of the respondent companies and had three questions to evaluate on the extent of digital marketing applications among the furniture manufacturers, both prior and during the COVID-19 pandemic. Part 2 evaluated the preferred contemporary digital marketing tools used within the furniture manufacturing industry. These questions collected information on the marketing medium used in the company and the types of digital platforms preferred among the respondent companies. Part 3 had questions that required the respondent companies to indicate the preferred social media tools used by a relative score, and the main reasons for using social media as a marketing tool were also evaluated. Part 4 required the respondents to indicate the effectiveness of digital marketing in the context of the furniture business based on the 5-point Likert scale score, and state the main challenges faced with relation to the adoption of digital marketing in the furniture industry. The questionnaire was designed to collect significant information according to market research that was valid, credible, and responsible (Papadopoulos et al. 2010).

An online survey was also conducted by the MFC, in which 69 randomly selected international furniture buyers, chosen from their database of participants at the annual 
Export Furniture Exhibition (EFE), to provide their opinions on the use of digital marketing tools for purchasing furniture. This part of the study provided the buyers perspective on the study, although the sample size was relatively small. In fact, the study also aimed to capture sufficient information to support the hypothesis that digital tools for marketing had been increasingly used during the pandemic, as opposed to the period prior to the onset of the pandemic. In this context, the responses from the companies about the effectiveness of digital marketing tools provided useful insights.

The survey responses were recorded in a spreadsheet and imported into the SPSS version 10.1 statistical analysis software (IBM, Armonk, NY, USA). The data were edited, processed, and analyzed using relative statistical tests, such as frequencies, descriptive statistics, crosstabs, and independence tests between all the variables using the $\chi^{2}$ criterion and correlation analysis. These tests were conducted based on the questionnaire's content validity and credibility which achieved the Cronbach-alpha score of 0.81 , as suggested previously by Winer (2009) and Mazzarol (2015).

\section{RESULTS AND DISCUSSION}

\section{Part I: Extent of Application of Digital Marketing among Furniture Manufacturers}

Figure 1 shows the sizes of the company respondents that participated in this study. Of the 743 respondent companies, $73 \%$ were SMEs, which suggested the prevalence of SMEs in the Malaysian furniture industry. To address whether the sample in this study was representative of the industry, the company-size distribution of the respondents in this study was compared to the data in the Malaysian Timber Industry Board's (MTIB) census on the wood industry of 2018. Cai and Aguilar (2014) used the same approach in a previous study, and it was found that such a comparison provided an accurate representation of the industry. The sample used in this study was comparable to the MTIB census data, where SMEs made up $82 \%$ of the manufacturing enterprises in the furniture sector.

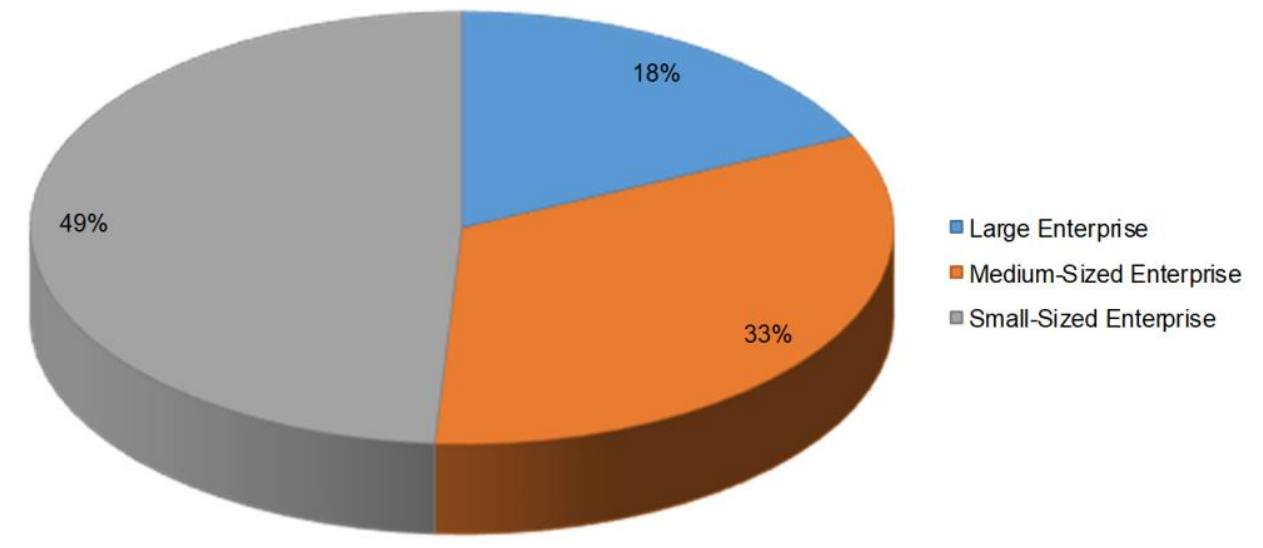

Fig. 1. Proportion of respondents by company size

Although the furniture and wood products industry has been relatively slow to adopt digital marketing compared to other industries, the uptake of digital marketing has been variable among the geographical regions. Studies in the United Stated and elsewhere, as reported by Vlosky and Westbrook (2002), Arano (2008), Montague and Wiedenbeck 
(2012), and Gazal et al. (2016), have confirmed that the adoption of digital marketing varies by region and industry. Previous studies in the United States have shown that digital marketing has the potential to help consumers make better research and purchasing decisions (Lamberton and Stephen 2016). In fact, digital marketing allows companies around the world to communicate with customers without any restrictions in the time, place, or medium (Kim and Ko 2012). Through digital marketing, communicating freely about products, brands, and companies has fostered the sense of belonging among consumers through interpersonal interactions and dialogue (Kim and Drumwright 2016). Inevitably, such practices create word-of-mouth advertising and aid in the consumer purchasing decision process.

It was apparent that the furniture manufacturing industry adopted digital marketing strategies prior to the COVID-19 pandemic (Fig. 2), although digital marketing was more prevalent among the large-sized furniture manufacturers as opposed to the SMEs. However, since the onset of the COVID-19 pandemic, the adoption of digital marketing among furniture manufacturers accelerated, regardless of the company size. This data was extracted from the questionnaire survey. Self-reporting by respondents made it possible to judge the extent of digital marketing application prior and during the pandemic period. The cancellation of the annual furniture exhibitions, especially the Malaysian International Furniture Fair (MIFF) and the EFE in 2020, due to the global travel restrictions and fear of infections, forced furniture manufacturers to explore other avenues to continue their marketing activities (MTIB 2020). Digital marketing became the obvious option, and together with the support from the government, furniture manufacturers embraced and adopted digital marketing strategies to connect with their existing customers and expand their presence in new markets. In essence, digital marketing provided a lifeline to furniture manufacturers to continue marketing activities during the uncertain times of the COVID19 pandemic.

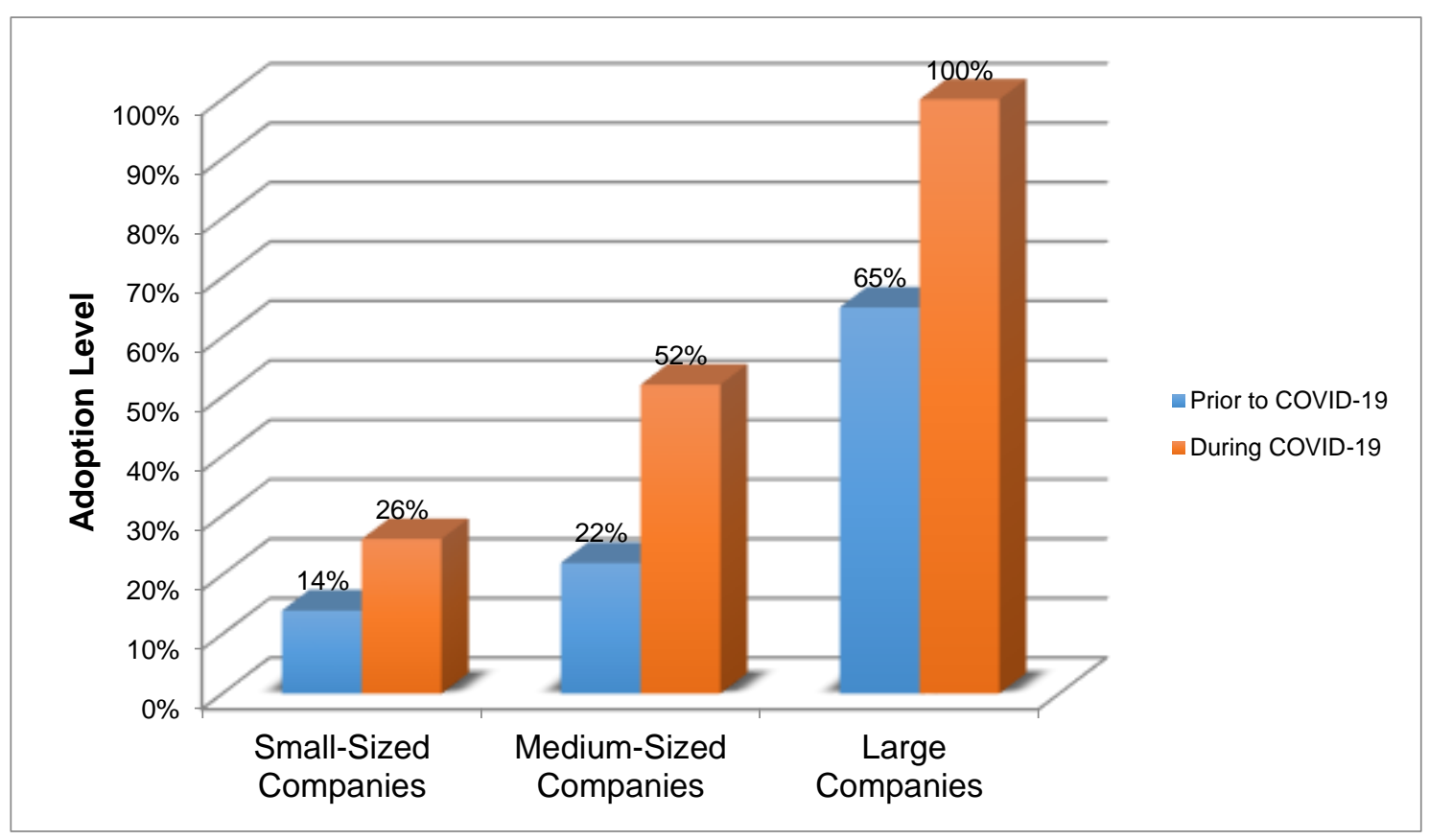

Fig. 2. Adoption of digital marketing by respondents prior to and during the COVID-19 pandemic 


\section{Part II: Preferences for Digital Marketing Tools among Furniture Manufacturers}

To determine which contemporary tools of digital marketing tool were preferred, the respondents were asked to indicate their preference for the major types of digital marketing tools commonly used. The list of the digital marketing tools was prepared after consultation with the MFC and several digital marketing experts familiar with the Malaysian business environment. The results of the choice of contemporary tools of digital marketing commonly used by the Malaysian furniture enterprises is shown in Fig. 3. The results from this study showed that the furniture enterprises in Malaysia mostly rely on websites (100\%), email marketing (83.8\%), social media marketing (71.6\%), and affiliate marketing (54.2\%), which is marketing through commission basis. Although Malaysian furniture enterprises are familiar with the operations of search engine optimization (SEO), its utilization rate was only $51.4 \%$. These results indicated that all the respondents in this study had a website to promote their company and products, which has been proven to turn visitors into potential customers. Through the provision of specific and targeted information to customers and potential customers alike, websites and emails have been the traditional marketing tools for furniture manufacturers over the last few decades (Vlosky and Westbrook 2002).

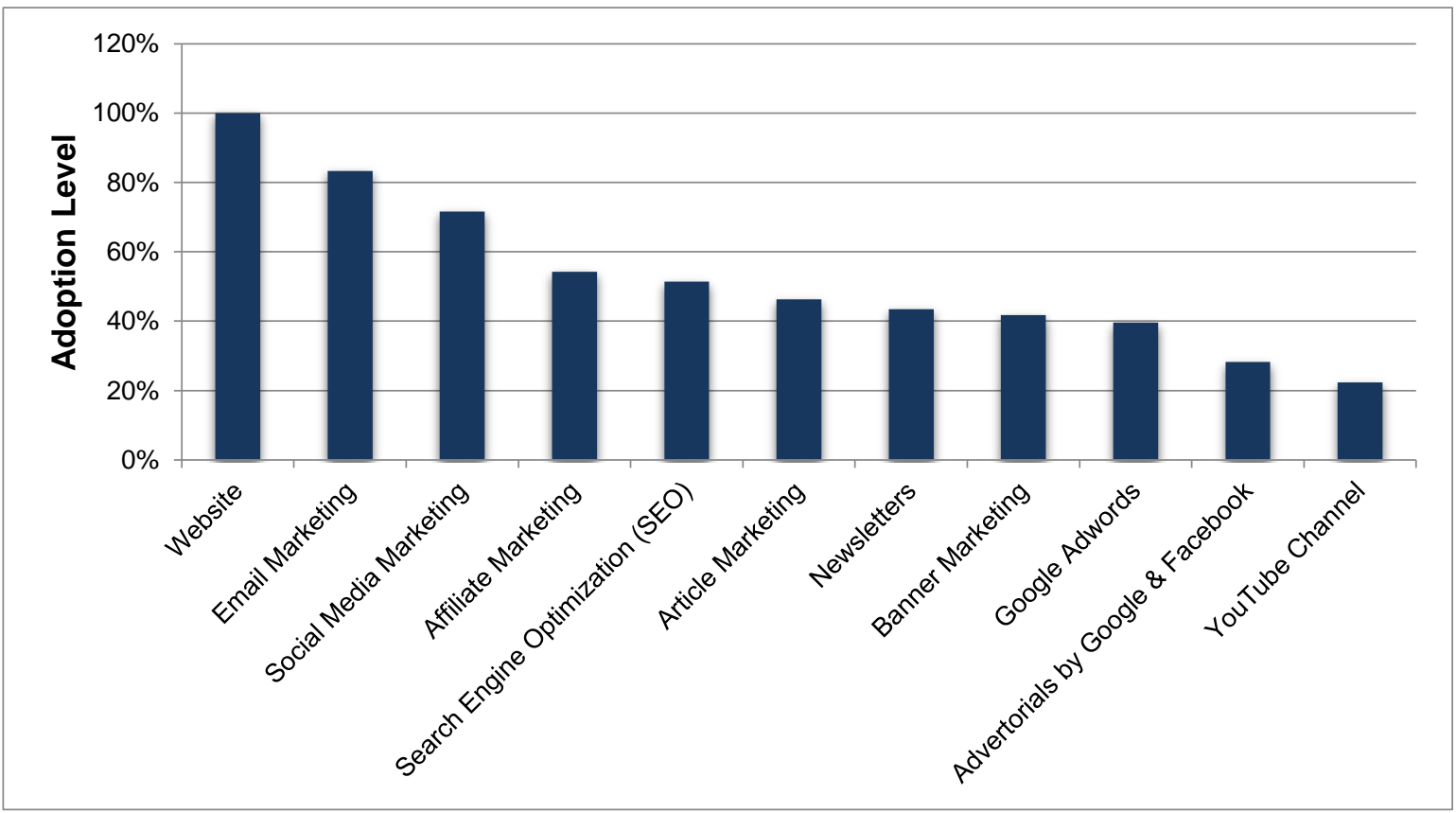

Fig. 3. The utilization of digital marketing tools among furniture manufacturers

The significance of implementing several digital marketing tools by the Malaysian furniture manufacturers on a 5-point Likert scale ranking is shown in Table 1. The significance of each marketing tool appeared to have a correlation with its utilization rate (Fig. 3).

Based on the correlation analysis between the various digital marketing tools using the Pearson's correlation coefficient $(P c c)$, the following correlations at a significance level of $(P<0.01)$ were observed. First, the use of the SEO is more prominent among companies that have their own websites $(P c c=0.657)$. This is expected since the information provided to the furniture enterprises by SEO are of great importance to improve the effectiveness of 
their respective website. Second, email marketing is highly correlated to the use of product newsletter towards many potential customers $(P c c=0.712)$. Third, banner marketing among furniture enterprises is positively correlated to article marketing $(P c c=0.781)$ and affiliate marketing $(P c c=0.709)$. Lastly, furniture enterprises that make greater use of SEOs tend to be more active in email marketing $(P c c=0.712)$ and article marketing $(P c c=0.604)$ simultaneously.

Table 1. The Relative Importance of Digital Marketing Tools used by Malaysian Furniture Manufacturers

\begin{tabular}{|c|c|c|}
\hline Tools of Internet Marketing & Mean & St. dev. \\
\hline Website & 4.49 & 0.651 \\
\hline Social Media Marketing & 3.74 & 1.483 \\
\hline Search Engine Optimization (SEO) & 3.60 & 1.443 \\
\hline Email Marketing & 3.32 & 1.600 \\
\hline Google Adwords & 2.94 & 1.459 \\
\hline Newsletters & 2.75 & 1.511 \\
\hline Article Marketing & 2.43 & 1.476 \\
\hline Advertorials by Google \& Facebook & 2.39 & 1.478 \\
\hline Banner Marketing & 2.21 & 1.572 \\
\hline Affiliate Marketing & 1.96 & 1.371 \\
\hline YouTube Channel & 1.90 & 1.353 \\
\hline
\end{tabular}

Note: $1=$ least used, 5 = highly used

Cross-tabulation also revealed that the adoption of digital marketing tools by furniture enterprises is statistically independent in relation to the company-size, and SMEs are equally active in the digital space as large-sized furniture manufacturers. The only statistically significant correlation is between the use of the SEO and social media marketing in relation to their company-size $\left(\chi^{2}=26.667\right.$ and $\chi^{2}=15.575$, respectively at $P<$ 0.001). Hence, large sized companies have an added advantage over SMEs when they adopt SEOs and social media marketing tools more effectively, due to the capacity to make higher investments.

\section{Part III: Application of Social Media Marketing Tools}

From the predetermined list of social media types, Facebook, YouTube, Twitter, Skype, Instagram, and Behance were the most preferred social media sites. Other social media platforms such as LinkedIn, geo-location sites, Myspace, Reddit, Quora, blogs, Google Plus, Pinterest, Whatsapp, WeChat, and Slide-share were not as popular among furniture producers (Fig. 4). Social media platforms are powerful, as they can promote and facilitate viral marketing, which can spread a company's message exponentially and allow the transmission of messages to thousands and even millions of viewers (Vilpponen et al. 2006; Gunawan and Huarng 2015). The widespread use of social media has made it an important factor that can influence consumer purchasing decisions. Hajli (2014) found that consumer trust in the suppliers is a critical factor that needs to be developed via social media communications to influence purchasing decisions. Chaffey (2016) found that the social media networking of the furniture manufacturers has a large influence on the purchasing behavior of consumers, so increasing efforts must be made to effectively build social-media marketing capacity for the furniture manufacturers. 


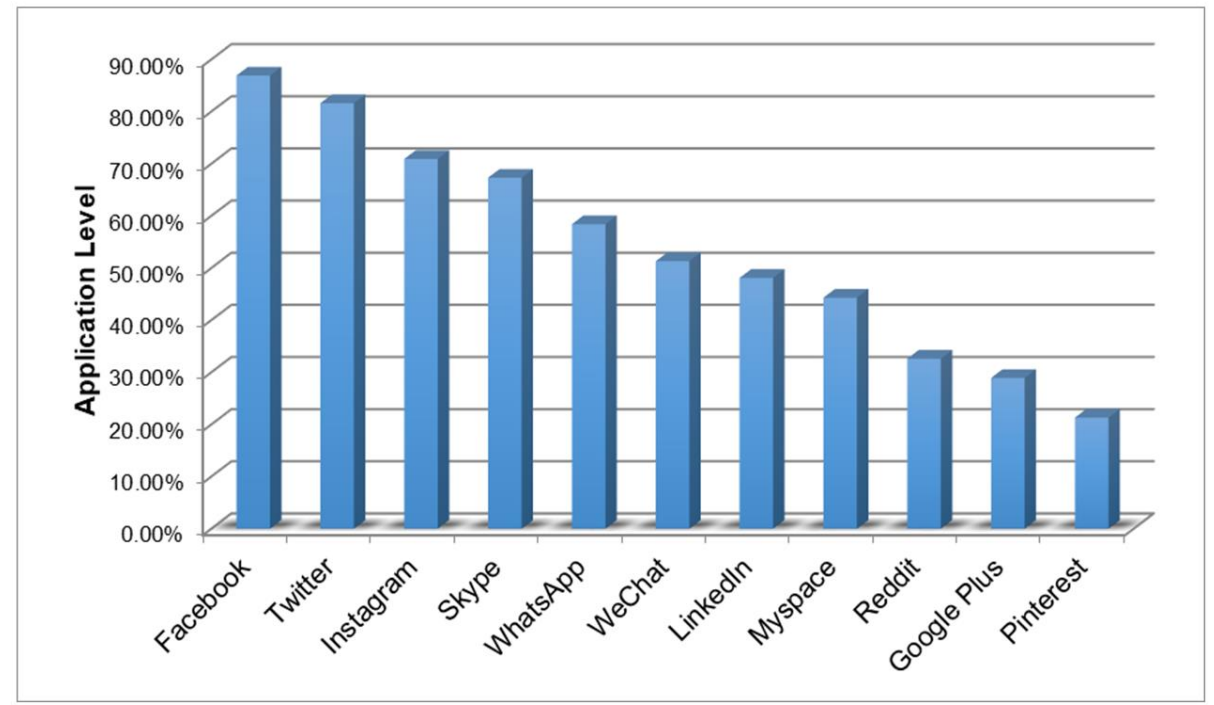

Fig. 4. The preferred social media tools among furniture manufacturers

Other studies on social media have found similar results when examining the most popular social media platforms in the United States (Montague et al 2016). According to Chaffey (2016), social media networks are so well established that there is now a "top 5" list of social networks that remain popular year after year. Unquestionably, Facebook is the most popular site in the world, followed by YouTube (Nadeem et al. 2015).

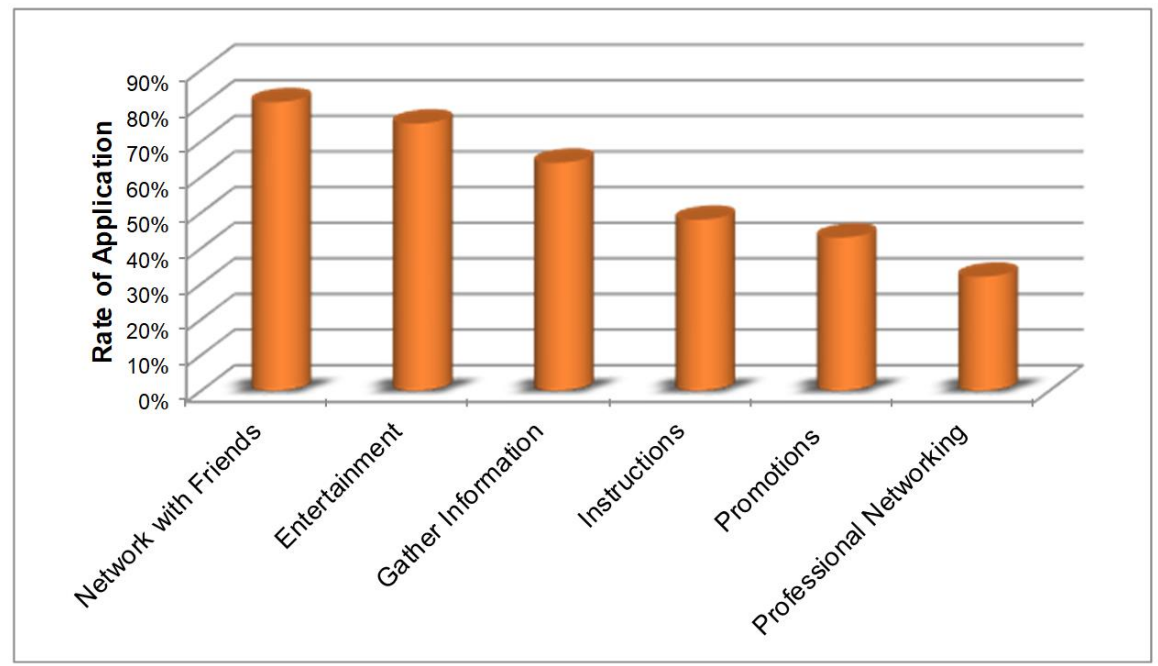

Fig. 5. Common reasons for using social media

To better understand current consumer social media trends, the respondents in this study were asked a series of questions to determine the reasons for social media use and its potential benefits. The respondents used social media for three primary reasons: to network with friends or colleagues in the furniture business, for entertainment purposes, and to gather information on the furniture industry and potential buyers (Fig. 5). Interacting with peers is a fundamental human act, and studies agree that peers are the primary agents of socialization, even before family members (Köhler et al. 2011; Wang et al. 2012). Furthermore, the respondents indicated that "liking" photos or other content related to 
products, sharing product content (photos, videos, etc.), and commenting on personal experiences with products were the top three activities they participated in as social media users. Wang et al. (2012) suggested that furniture purchasing decisions are always triggered through words-of-mouth, and social media often facilitates prompt information transmission about products and buyers.

\section{Part IV: Effectiveness and Challenges to Digital Marketing Applications in the Furniture Industry}

The results from the study showed that $87 \%$ of the respondents agreed that digital marketing was a viable path forward in the furniture business, but only $36 \%$ of the respondents agreed that digital marketing was effective in furniture marketing. Of the respondents, $64 \%$ indicated that a hybrid marketing medium that consisted of both physical and digital marketing activities would be more appropriate for the furniture industry. The hesitation of furniture manufacturers to pursue digital marketing could be attributed to the lack of technology-savvy workers, insufficient digital connectivity in Malaysia, insufficient band width to support complex platforms, and most importantly, the lack of skills and knowledge among the furniture manufacturers to improve their content presentation and exploit the powers of digital marketing. Similar weaknesses were also highlighted in a report by the Multimedia Development Corporation (2020), who found that a lack of skilled and knowledgeable workers stifles the greater adoption of digital marketing tools in many industries, including the furniture manufacturing sector. In this context, it is particularly difficult for SMEs to adopt digital marketing strategies because they lack the funds necessary to boost connectivity and hire the necessary IT workers (Lee and Ishak 2020).

\section{Part V: Perception of Buyers on Digital Marketing}

Based on the survey conducted by the MFC among the 69 international furniture buyers, it was found that $74 \%$ of the international furniture buyers depended on SEO tools to decide on new furniture suppliers during the COVID-19 pandemic. However, the final purchasing decision is only made after gathering information about the manufacturer's reputation and the promotions offered through social-media and email marketing. On the other hand, $22 \%$ of the respondents indicated that their choice of suppliers is often dictated by the information gathered through social-media marketing, while only $4 \%$ would prefer a hybrid-marketing medium that involves both physical and digital marketing tools. A similar observation was noted by previous studies (Kim and Ko 2012; Ratnasingam 2017), indicating that international furniture buyers have embraced digital marketing more readily compared to furniture manufacturers in Malaysia. Inevitably, the results suggest that furniture manufacturers in Malaysia will need to embrace and adopt digital marketing more readily, especially SEO tools, to compete in the global marketplace, especially during the COVID-19 pandemic.

\section{Industrial Implications}

The results from this study are parallel to several other studies in this area by Kim and Ko (2012), Constantinides (2014), and Montague et al. (2016). However, it must be recognized that the SMEs in the furniture industry lag in the uptake of digital marketing tools compared to other manufacturing sectors in the country. This trend could be attributed to the unpreparedness of the companies, the lack of know-how as well as skilled personnel to build on such capability. The study shows that despite the huge potential and advantages 
offered by digital marketing, the full potential of digital marketing within the furniture industry remains to be fully exploited. However, as highlighted by Ratnasingam et al. (2020), more assistance to boost the application of digital marketing must be provided if the SMEs in the furniture industry are to take advantage of digital marketing in an era when marketing activities are severely inhibited due to the COVID-19 pandemic. One drawback of this study is the limited participation of many micro-enterprises, which fulfill subcontracts in the whole supply-chain within the furniture manufacturing industry. Their inputs, especially with regard to the benefits gained from digital marketing, would have provided very useful insights for the overall objective of the study.

Results of this study suggest that the Malaysian furniture manufacturers had embraced digital marketing to varying degrees, with the larger companies investing more in digital marketing tools compared to the SMEs. Although the onset of the COVID-19 pandemic accelerated the adoption of digital marketing tools, larger companies continue to have an upper hand in its adoption. Therefore, it appears that the Malaysian government's targeted assistance programs aimed at boosting digital marketing among SMEs during the COVID-19 pandemic has not achieved the intended degree of targeted adoption due to the poor digital outlay among many of the furniture SMEs. Although social media and email marketing was also commonly used among furniture manufacturers, the lack of a strategic approach in handling digital marketing has affected its effectiveness for SMEs in the furniture sector. On the other hand, furniture is often purchased on the perceived value rather than the actual value, so a strategic approach for digital marketing initiatives that can deliver the benefits offered by the traditional physical furniture marketing medium is required. In this context, the adoption of digital marketing among furniture manufacturers would require a strategic approach that must also be supported by skilled and knowledgeable workers to support the digital marketing initiatives. The employed digital marketing tools must be able to convey the value of furniture in an online format to entice potential customers to make a purchase. Such an approach will require a variety of digital tools, which at this point is not quite available to the furniture manufacturers in Malaysia. Therefore, it is important that policy makers review the results from this study to ensure the effective adoption of digital marketing in the furniture industry and to provide the necessary support to ensure that the furniture industry remains competitive in the future.

\section{CONCLUSIONS}

1. Although Malaysian furniture manufacturers adopted digital marketing techniques to some extent prior to the onset of the COVID-19 pandemic, its adoption was accelerated during the pandemic. However, the utilization rate of digital marketing platforms varied among companies depending on their size.

2. Company websites, email marketing, and social media marketing were the three most common digital marketing tools used by furniture manufacturers.

3. In terms of social media marketing, Facebook, Twitter, and Instagram were the most common social media marketing platforms utilized by furniture manufacturers.

4. Despite their familiarity with digital marketing, some furniture manufacturers have not been using digital platforms to an extent large enough to achieve optimal potential benefits. This could be attributed to the lack of skilled and knowledge workers that 
can exploit the powers of digital marketing in the furniture business.

5. Furniture buyers utilize SEO digital marketing tools to identify potential suppliers, so furniture manufacturers need to ensure that they adopt SEO tools to enhance their chances of engaging with international furniture buyers.

\section{ACKNOWLEDGEMENTS}

The authors are grateful to the Malaysian Furniture Council (MFC) for the assistance with implementation of the survey and data sharing. The authors would also like to acknowledge the Universiti Putra Malaysia (UPM) for the financial assistance through the PUTRA-Grant No. 9649900, which was necessary to carry out this study.

\section{REFERENCES CITED}

Albors, J., Ramos, J. C., and Hervas, J. L. (2008). "New learning network paradigms: Communities of objectives, crowdsourcing, wikis and open source," International Journal of Information Management 28(3), 194-202. DOI:

10.1016/j.ijinfomgt.2007.09.006

Arano, K. G. (2008). "Electronic commerce adoption in West Virginia's primary and secondary hardwood industries: Preliminary results," in: Proceedings of the 2008 Southern Forest Economics Workers (SOFEW) Annual Meeting, Savannah, GA, pp. 72-81.

Barwise, P. and Styler, A. (2003). Marketing Expenditure Trends: 2001-2004. London Business School, London, UK.

Cai, Z., and Aguilar, F. X. (2014). "Corporate social responsibility in the wood products industry: US and Chinese consumers' perceptions," Forest Products Journal 64(3-4), 97-106. DOI: 10.13073/FPJ-D-13-00059

Chaffey, D. (2016). "Global social media research summary 2016," Smart Insights: Social Media Marketing, (https://www.smartinsights.com/social-mediamarketing/social-media-strategy/new-global-social-media-research/), Accessed May $16,2018$.

Clarke, G. R. G. (2008). "Has the internet increased exports for firms from low and middle-income countries?," Information Economics and Policy 20(1), 16-37.

Constantinides, E. (2014). "Foundations of social media marketing," Procedia - Social and Behavioral Sciences 148, 40-57. DOI: 10.1016/j.sbspro.2014.07.016

Drury, G. (2008). "Opinion piece: Social media: Should marketers engage and how can it be done effectively?," Journal of Direct, Data and Digital Marketing Practice 9(3), 274-277. DOI: 10.1057/palgrave.dddmp.4350096

Eid, R., and El-Gohary, H. (2011). "The impact of E-marketing use on small business enterprises' marketing success,” The Service Industries Journal 33(1), 31-50. DOI: 10.1080/02642069.2011.594878

Gazal, K., Montague, I., Poudel, R., and Wiedenbeck, J. (2016). "Forest products industry in a digital age: Factors affecting social media adoption," Forest Products Journal 66(5-6), 343-353. DOI: 10.13073/FPJ-D-15-00007

Gunawan, D. D., and Huarng, K.-H. (2015). "Viral effects of social network and media 
on consumers' purchase intention," Journal of Business Research 68(11), 2237-2241. DOI: $10.1016 /$ j.jbusres.2015.06.004

Hajli, M. N. (2014). "A study of the impact of social media on consumers," International Journal of Market Research 56(3), 387-404. DOI: 10.2501/IJMR-2014-025

Hamill, J., and Gregory, K. (1997). "Internet marketing in the internationalisation of UK SMEs," Journal of Marketing Management 13(1-3), 9-28. DOI: 10.1080/0267257X.1997.9964456

Hoffman, D. L., Novak, T. P., and Chatterjee, P. (1995). "Commercial scenarios for the web: Opportunities and challenges," Journal of Computer-Mediated Communication 1(3), 16-37. DOI: 10.1111/j.1083-6101.1995.tb00165.x

Jarvenpaa, S. L., and Todd, P. A. (1996). "Consumer reactions to electronic shopping on the world wide web" International Journal of Electronic Commerce 1(2), 59-88. DOI: $10.1080 / 10864415.1996 .11518283$

Kim, J. H., Bae, Z.-T., and Kang, S. H. (2008). "The role of online brand community in new product development: Case studies on digital product manufacturers in Korea," International Journal of Innovation Management 12(3), 357-376. DOI: 10.1142/S1363919608002011

Kim, A. J., and Ko, E. (2012). "Do social media marketing activities enhance customer equity? An empirical study of luxury fashion brand," Journal of Business Research 65(10), 1480-1486. DOI: 10.1016/j.jbusres.2011.10.014

Kim, E., and Drumwright, M. (2016). "Engaging consumers and building relationships in social media: How social relatedness influences intrinsic vs. extrinsic consumer motivation," Computers in Human Behavior 63, 970-979. DOI: 10.1016/j.chb.2016.06.025

Köhler, C. F., Rohm, A. J., de Ruyter, K., and Wetzels, M. (2011). "Return on interactivity: The impact of online agents on newcomer adjustment," Journal of Marketing 75(2), 93-108. DOI: 10.1509/jm.75.2.93

Kotler, P. (1997). Marketing Management: Analysis, Planning, Implementation, and Control, Prentice Hall, Upper Saddle River, NJ.

Lamberton, C., and Stephen, A. T. (2016). "A thematic exploration of digital, social media, and mobile marketing: Research evolution from 2000 to 2015 and an agenda for future inquiry," Journal of Marketing 80(6), 146-172. DOI: 10.1509/jm.15.0415

Lee, M. M., and Ishak, H. I. (2020). Information Technology Workers Requirement in the Malaysian Wood Industry, Ministry of Labour Publication, Kuala Lumpur, Malaysia.

Lim, J.-S., Sharkey, T. W., and Kim, K. I. (1993). "Determinants of international marketing strategy," Management International Review 33(2), 103-120.

Mathews, S., and Healy, M. J. (2007). "The internet and information capability reduces perceived risk of internationalisation: An Australian SME perspective," International Journal of Organisational Behaviour 12(1), 71-87.

Mazzarol, T. (2015). "SMEs engagement with e-commerce, e-business and e-marketing," Small Enterprise Research 22(1), 79-90. DOI: 10.1080/13215906.2015.1018400

MIDA. (2019). Status of Investments in the Malaysian Manufacturing Sector, Malaysian Industry Development Authority Annual Report, Kuala Lumpur, Malaysia.

Montague, I. B., and Wiedenbeck, J. (2012). "Cultivating connections in 2012 - Web strategies used by forest products businesses in the southern US," in: Proceedings of the 2012 Southern Forest Economics Workers (SOFEW) Annual Meeting, Charlotte, NC, pp. 112-124.

Montague, I., Gazal, K. A., Wiedenbeck, J., and Shepherd, J.-G. (2016). "Forest products 
industry in a digital age: A look at e-commerce and social media," Forest Products Journal 66(1-2), 49-57. DOI: 10.13073/FPJ-D-14-00104

MTIB. (2020). Annual Performance of the Malaysian Wood Products Sector, Malaysian Timber Industry Board Publication, Kuala Lumpur, Malaysia.

Multimedia Development Corporation (2020). Status of Digital Economy in Malaysia, Multimedia Development Corporation (Report No. 16.), Kuala Lumpur, Malaysia. Nadeem, W., Andreini, D., Salo, J., and Laukkanen, T. (2015). "Engaging consumers online through websites and social media: A gender study of Italian generation Y clothing consumers," International Journal of Information Management 35(4), 432442. DOI: 10.1016/j.ijinfomgt.2015.04.008

Papadopoulos, I., Karagouni, G., Trigkas, M., and Platogianni, E. (2010). “Green marketing: The case of Greece in certified and sustainable managed timber products," EuroMed Journal of Business 5(2), 166-190. DOI: 10.1108/14502191011065491

Papadopoulos, I., Trigkas, M, and Karagouni, G. (2015). "Consumer-based value creation in launching green and smart innovation within the furniture industry; The case of the GSF research project," in: Conference Proceedings of $3^{\text {rd }}$ International Conference on Contemporary Marketing Issues (ICCMI), London, UK, pp. 444-449.

Ratnasingam, J. (2017). Furniture and Wood Products Marketing in the ASEAN regionChallenges in the Digital World, International Furniture Research Group (IFRG) Publication No. 14-MR, Singapore.

Ratnasingam, J. and Lee, Y. Y. (2015). Starting up a Furniture Business - A Guide for Entrepreneurs, Universiti Putra Malaysia Press, Serdang, Malaysia.

Ratnasingam, J., Khoo, A., Jegathesan, N., Wei, L. C., Ab Latib, H., Thanasegaran, G., Liat, L. C., Yi, L. Y., Orhman, K., and Amir, M. A. (2020). "How are small and medium enterprises in Malaysia's furniture industry coping with the COVID-19 pandemic: Early evidences from a survey and recommendations for policymakers," BioResources 15(3), 5951-5964. DOI: 10.15376/biores.15.3.5951-5964

Small \& Medium Enterprises Corporation (2021). Status of Small and Medium Enterprises in Malaysia During the COVID-19 Pandemic (Report No. 14A-1), Petaling Jaya, Malaysia.

Vilpponen, A., Winter, S., and Sundqvist, S. (2006). "Electronic word of-mouth in online environments," Journal of Interactive Advertising 6(2), 8-77.

DOI: $10.1080 / 15252019.2006 .10722120$

Vlosky, R. P., and Westbrook, T. (2002). "eBusiness exchange between homecenter buyers and wood products suppliers," Forest Products Journal 52(1), 38-43.

Wang, X., Yu, C., and Wei, Y. (2012). "Social media peer communication and impacts on purchase intentions: A consumer socialization framework," Journal of Interactive Marketing 26(4), 198-208. DOI: 10.1016/j.intmar.2011.11.004

Winer, R. S. (2009). "New communications approaches in marketing: Issues and research directions," Journal of Interactive Marketing 23(2), 108-117.

DOI: 10.1016/j.intmar.2009.02.004

Article submitted: February 2, 2021; Peer review completed: March 6, 2021; Revised version received and accepted: March 16, 2021; Published: March 18, 2021.

DOI: $10.15376 /$ biores.16.2.3304-3317 